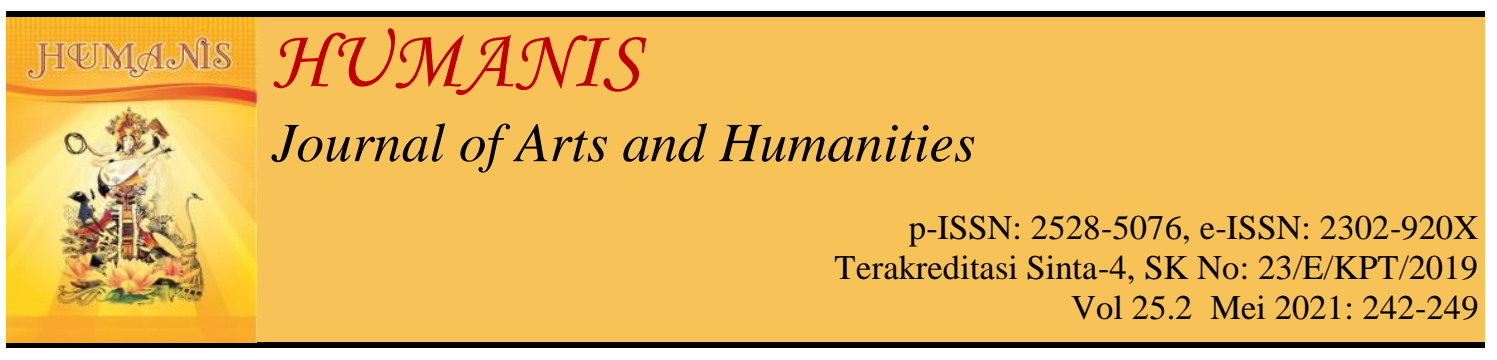

\title{
Perubahan Sosial Budaya Nelayan Pesisir Kedungrejo
}

\author{
Wahyu Tianingsih, I Nyoman Sama, I Ketut Kaler \\ Universitas Udayana, Denpasar, Bali, Indonesia \\ Email korespondensi: tia231998@gmail.com,nyoman.sama@gmail.com, \\ iketutkaler@gmail.com
}

\begin{tabular}{l}
\hline Info Artikel \\
\hline Masuk: 18 Maret 2021 \\
Revisi: 7 Mei 2021 \\
Diterima: 24 Mei 2021 \\
Keywords: fishing community, \\
technology, sea picking \\
tradition, low season \\
\\
Kata kunci: masyarakat \\
nelayan, teknologi, tradisi petik \\
laut, musim paceklik \\
Corresponding Author: \\
Wahyu Tianingsih \\
Email: tia231998@gmail.com \\
DoI: \\
https://doi.org/10.24843/JH.20 \\
21.v25.i02.p13 \\
\hline
\end{tabular}

\begin{abstract}
This study aims to reveal the various dynamics and attitudes of the Madurese fishing community towards changes in Kedungrejo Village. Based on the results of the analysis, this research is divided into four parts, the first is the change in Kedungrejo fishing technology from traditional to modern. Second, changes to the sea-picking ritual tradition. Third, changes in the strategy of the Kedungrejo fishing community in facing the dry season. Fourth, the attitude of the Madurese fishing community towards changes in Kedungrejo Village. Changes greatly affect the conditions that exist in the fishing community in this village, especially social and cultural values.

\begin{tabular}{l}
\hline Abstrak \\
\hline Penelitian ini bertujuan untuk mengungkap berbagai dinamika \\
serta sikap masyarakat nelayan Madura terhadap perubahan di \\
Desa Kedungrejo. Berdasarkan hasil analisis penelitian ini \\
terpilah menjadi empat bagian, pertama perubahan teknologi \\
nelayan Kedungrejo dari yang semula tradisional menjadi \\
modern. Kedua, perubahan pada tradisi ritual petik laut. \\
Ketiga, perubahan strategi masyarakat nelayan Kedungrejo \\
dalam menghadapi musim paceklik. Keempat, sikap masyarakat \\
nelayan Madura terhadap perubahan di Desa Kedungrejo. \\
Perubahan sangat mempengaruhi kondisi yang ada dalam \\
masyarakat nelayan di Desa ini, khususnya nilai sosial dan \\
nilai kebudayaan.
\end{tabular}
\end{abstract}

\section{PENDAHULUAN}

Indonesia adalah negara maritim karena merupakan negara yang memiliki banyak pulau diantaranya selat, danau, dan laut. Wilayah indonesia sangat didominasi dengan perairan atau laut sehingga wajar bila masyarakat Indonesia yang bermukim di daerah pantai bersumber penghasilan pada pekerjaan sebagai nelayan (Iriani et al, 2001).
Pada dasarnya masyarakat nelayan hidupnya bertumpu pada penghasilan laut (Wardiat, 2017). Kemampuan masyarakat nelayan dalam melaut sebagian besar diperoleh secara turuntemurun dari nenek moyang mereka. Alasan utama yang mendorong masyarakat menekuni pekerjaan sebagai nelayan adalah untuk bertahan hidup. Masyarakat nelayan memiliki karakter 
yang bersifat berubah-ubah atau dinamis mengikuti sumberdaya alam, maka untuk perolehan maksimal para nelayan harus berpindah tempat dan memperluas sasaran tangkap. Selain itu, mata pencaharian sebagai nelayan memiliki resiko yang cukup tinggi dengan menghadapi perubahan alam setiap waktu yang tidak bisa diprediksi sehingga penghasilan nelayan tidak pasti (Zamzami: 2016).

Masyarakat tradisional dan modern selalu mengalami perubahan sosial seiring waktu (Husen, 2015). Masyarakat modern mengalami revolusi sangat cepat karena mendapat pengaruh dari budaya luar, sedangkan masyarakat tradisional mengalami perubahan atau dinamika yang sangat lambat karena mereka sukar untuk berkembang dan menerima pengaruh dari luar

Dinamika perubahan sosial yaitu pergerakan atau pergeseran kehidupan masyarakat dalam konteks pembangunan yang berlangsung secara perlahan maupun secara cepat (Purwati, 2017).

Terdapat pengaruh dinamika yang signifikan dalam teori perubahan sosial yaitu maju mundurnya perubahan masyarakat tergantung penerimaan masyarakat terhadap pengaruh internal maupun eksternal yang ada.

Hal tersebut seperti yang terjadi pada masyarakat pesisir Desa Kedungrejo, terdapat perubahan sosial maupun budaya menjadi kemajuan (progress) di daerah tersebut, dari arah tradisional menuju arah modern pada teknologi penangkapan ikan serta kebudayaannya (Lucky, 2009).

Pada tahun 2015, masyarakat nelayan Kedungrejo masih menggunakan alat tradisional untuk menangkap ikan sehingga hasil tangkapan tidak mencukupi kebutuhan sehari-hari sebab belum maksimal dalam pengelolaan sumber daya alam. Penyebab dari ketertinggalan teknologi masyarakat nelayan Kedungrejo adalah keterbatasan pendidikan, kurangnya perhatian dari pemerintah, kurangnya wawasan tentang pemahaman teknologi modern serta keterbatasan modal usaha dalam perkembangan masyarakat. (Wahyuningsih, 2015).

Kehidupan ekonomi nelayan di Desa Kedungrejo bergantung sepenuhnya pada potensi hasil laut. Usaha untuk memenuhi kebutuhan rumah tangga umumnya bertumpu pada penangkapan ikan serta hasil dari penjualan ikan tersebut. Kemudian, unsur terpenting dalam penangkapan ikan bagi masyarakat nelayan adalah teknologi alat tangkap atau sarana untuk penangkapan (perahu), masyarakat desa Kedungrejo harus mempunyai Strategi adaptasi karena bermanfaat untuk memenuhi kebutuhan sehari-hari namun tetap menjaga ekosistem laut. Strategi adaptasi nelayan meliputi kemampuan masyarakat nelayan dalam merespon kemajuan ilmu pengetahuan dan teknologi (IPTEK), lingkungan, politik, serta sosial budaya.

Berbagai Suku di Indonesia memiliki kebudayaan serta tradisi yang menjadi ciri khas dan sebagai identitas bagi suku tersebut. Dalam suatu kebudayaan pasti terdapat peran masyarakat di dalamnya, begitu juga sebaliknya dalam suatu masyarakat pasti tercipta suatu kebudayaan. Masyarakat berperan sebagai pelaku serta pendukung kebudayaan. Dimana anggota masyarakat pada suatu suku sangat memegang erat nilai budaya dan adat istiadat dari para leluhurnya (Wahyu, 2016).

Suku Madura merupakan salah satu suku di Indonesia yang memegang erat tradisi turun-temurun yang diwariskan dari leluhurnya. Tradisi adalah pengendali sikap dan sifat masyarakat yang mematuhinya. Kadangkala tradisi tersebut dapat dilihat dari jiwa dan kehidupan masyarakat itu sendiri, dan sebagai cirikhas suatu masyarakat di sebuah daerah. Masyarakat sangat bergantung pada tradisi serta 
kepercayaannya (Simanjuntak, 2016). Hingga sampai saat ini masyarakat masih menggelar berbagai macam tradisi karena dianggap sebagai kewajiban yang harus dilakukan setahun sekali atau beberapa tahun sekali.

Lokasi penelitian merupakan komponen penting dalam suatu penelitian, dalam penulisan jurnal ini, lokasi penelitian untuk penulisan berlokasi di Desa Kedungrejo Kecamatan Muncar Kabupaten Banyuwangi. Penentuan lokasi ini berdasarkan pada beberapa pertimbangan, pertimbangan tersebut antara lain karena masyarakat Desa Kedungrejo mayoritas penduduknya dari suku Madura yang merupakan pendatang yang menetap di daerah pesisir tersebut, bermata pencaharian sebagai nelayan yang lambat laun teknologi, kebudayaan sosialnya semakin berubah.

Berdasarkan uraian latar belakang masalah tersebut, peneliti dapat merumuskan dua permasalahan diantaranya (1.) Bagaimana Dinamika Sosial Budaya Masyarakat Nelayan Madura Di Desa Kedungrejo, Kecamatan Muncar, Banyuwangi?, Serta

Bagaimana Strategi Masyarakat Nelayan Desa Kedungrejo Bertahan Hidup Dalam Musim Paceklik?.

\section{METODE}

Penelitian ini menggunakan metode observasi partisipasi, dimana peneliti secara langsung terjun kelapangan untuk berpartisipasi dan terlibat dalam kegiatan yang diamati di masyarakat nelayan Kedungrejo (Yusuf, 2017). Pada saat penelitian, peneliti akan tinggal bersama salah satu warga Pesisir Desa Kedungrejo untuk berpartisipasi dalam kegiatan sehari-hari masyarakat nelayan, dan tentunya berpartisipasi dalam menyiapkan segala kebutuhan yang akan digunakan nelayan dalam melaut. Selain itu, peneliti juga melakukan wawancara untuk mengumpulkan data dalam penelitian melalui metode tanya jawab secara langsung atau tatap muka antara peneliti dan para informan mengenai dinamika teknologi nelayan, dinamika tradisi petik laut, dan perubahan strategi masyarakat dalam menghadapi musim paceklik (Yusuf, 2017).

Pada penelitian ini, penulis menggunakan data primer dan data sekunder. Data primer adalah data yang diperoleh peneliti dari lapangan melalui observasi dan wawancara atau interview secara mendalam kepada para informan, selain itu peneliti menggunakan data sekunder yang diperoleh peneliti dari studi kepustakaan dan digunakan sebagai data penunjang (Mulyadi, 2011). Penelitian ini juga menggunakan metode analisis data yaitu analisis data deskriptif kualitatif yang bersifat holistik atau menyeluruh mengenai objek penelitian. Penelitian ini menggunakan Teori Perubahan Sosial oleh William F. Ogburn yang dianggap relevan untuk mengkaji permasalahan dalam penelitian ini (Marzali, 2006).

\section{HASIL DAN PEMBAHASAN}

\section{Dinamika Teknologi Masyarakat Nelayan di Desa Kedungrejo Muncar}

Sejak tahun 2011 teknologi masyarakat nelayan Kedungrejo perlahan berubah menjadi lebih modern sehingga ikan sasaran tangkapnya menjadi ikan demersial dan jangkauan tangkapnya pun semakin luas. Nelayan yang sebelumnya menggunakan perahu layar diganti mesin penggerak yang mempunyai sistem kerja yang efektif dan efisien, sedangkan alat tangkap tradisional diganti dengan alat tangkap yang lebih modern seperti alat tangkap Gill net. Perubahan alat tangkap ini diwilayah perairan Kedungrejo Muncar mempunyai pengaruh besar terhadap hasil produksi tangkapan nelayan sesudah menggunakan perahu mesin dan alat tangkap Gill net. Kondisi ini menyebabkan berkembangnya armada 
perahu dan alat tangkap ikan nelayan Desa kedungrejo Kecamatan Muncar.

\section{Dinamika Tradisi Petik Laut masyarakat nelayan Madura di Desa Kedungrejo}

Kebudayaan berarti akal budi, adatistiadat, serta pikiran. Pengertian kebudayaan berasal dari kata budaya yang merupakan hasil pola pikir manusia itu sendiri. Kebudayaan tersebut adalah hasil karya fisik sekelompok manusia yang menjadi ciri khas dan sebagai identitasnya. Hasil dari kebudayaan berwujud benda-benda fisik atau artifacts, tindakan serta tingkah laku masyarakat (Setiawan, 2016).

Diberbagai daerah di pulau Jawa, masyarakat pesisir memiliki ritual slametan laut dengan berbagai ciri khas tersendiri dengan nama yang berbedabeda. Misalnya di Madura dikenal dengan sebutan "rokaatan", sedangkan di Kota Lamongan masyarakat menyebutnya "tutup layang", dan di Banyuwangi tepatnya di daerah pesisir Kecamatan Muncar, masyarakat akrab menyebutnya dengan ritual petik laut. Upacara atau ritual ini rutin diselenggarakan setiap tahun sekali pada awal bulan muharram atau bulan Suro oleh masyarakat pesisir Kedungrejo (Setiawan, 2016). Terdapat akulturasi dalam tradisi ritual ini, yaitu antara nilai budaya lokal dan unsur agama islam. Dalam Ritual petik laut kini mengalami transformasi, awalnya berdasar pada unsur animisme dan dinamisme, seiring waktu berkembang ke dalam wujud yang berlandaskan pada keyakinan agama islam. Tradisi petik laut merupakan fenomena kebudayaan yang memiliki artefak, aktifitas, serta unsur gagasan yang merupakan percampuran antara agama islam dengan budaya lokal. Transformasi tersebut berupa, dulu tradisi petik laut hanya acara selametan biasa, namun seiring waktu terdapat perkembangan, yaitu kini Tradisi petik laut diselenggarakan secara kolosal, terdapat panitia formal yang mengatur suksesnya acara.

\section{Dinamika Strategi nelayan Madura dalam bertahan hidup pada Musim Paceklik}

Para nelayan pada umumnya menghadapi musim paceklik dan musim panen. Musim panen masyarakat nelayan adalah pada saat mereka memperoleh hasil laut sebagai penghasilan untuk kebutuhan mereka sehari-hari. Sedangkan Musim paceklik merupakan masa sulit nelayan dalam mencari penghasilan. Pada Musim panen, masyarakat nelayan bisa mendapatkan penghasilan dari penjualan hasil tangkapan dari laut saat cuaca bersahabat sehingga ombak stabil. Namun jika musim paceklik tiba, masyarakat nelayan tidak mendapatkan hasil tangkapan dari laut karena cuaca yang tidak stabil dan mengakibatkan ombak tinggi. Musim paceklik merupakan suatu hambatan bagi masyarakat nelayan dalam mencari ikan, hal tersebut karena faktor cuaca ekstrim sehingga para nelayan tidak berani untuk melaut (Sajogyo dan Pudjiwati, 1996). Alhasil saat musim paceklik tiba, para nelayan menganggur dan tidak memiliki penghasilan.

Musim paceklik ikan merupakan masa dimana masyarakat nelayan mengalami krisis moneter, sehingga memunculkan permasalahan baru yaitu banyak nelayan Desa Kedungrejo meminjam uang pada lintah darat (rentenir), KSP (Koperasi simpan pinjam), maupun Bank kecil yang membebani bunga pinjaman sangat tinggi, hal tersebut untuk memenuhi kebutuhan sehari-hari dan sekolah anaknya. Setelah menganggur berbulanbulan selama paceklik, akhirnya masyarakat nelayan bingung untuk melunasi hutang-hutangnya sehingga tidak ada solusi lain selain menggadaikan barang-barang atau menjualnya dengan 
menggelar pasar "piring terbang". Piring terbang merupakan kebiasaan masyarakat nelayan Kedungrejo saat mengalami kesulitan pada musim paceklik.

\section{Perubahan Strategi Masyarakat Nelayan dalam Menghadapi Musim Paceklik}

Setelah tahun 2016, masyarakat nelayan Kedungrejo sudah tidak mengadakan fenomena piring terbang lagi dan para istri nelayan beralih mencari kerang di pesisir Kedungrejo saat air surut untuk bertahan hidup dimusim paceklik. Kerang tersebut biasanya dijual di pasar Kedungrejo secara langsung (kerang segar) maupun kerang yang melalui proses pengolahan menjadi kerupuk kerang, sisanya dikonsumsi sendiri untuk dijadikan lauk keluarga nelayan Kedungrejo. Sehingga kehidupan masyarakat nelayan Kedungrejo kini lebih sejahtera dan sudah tidak meminjam uang pada lintah darat (rentenir), KSP (Koperasi simpan pinjam), maupun Bank kecil. Hal tersebut sebagai hasil dari kebijakan pemerintah yang mengadakan penyuluhan kepada masyarakat nelayan untuk menghadapi muslim paceklik.

\section{Sikap Masyarakat Nelayan Terhadap Perubahan Di Desa Kedungrejo, Kecamatan Muncar, Banyuwangi.}

Dalam proses perubahan pada masyarakat, selalu mengakibatkan masalah baru karena masyarakat tersebut tidak langsung dapat menerima dan mengadopsi perubahan tersebut tergantung dengan kondisi dan nilai-nilai yang berlaku pada masyarakat itu sendiri. Sebagian masyarakat menilai perubahan yang terjadi tersebut dapat diterima dengan baik karena beranggapan bahwa kondisi lama harus dirubah atau ditinggalkan sehingga tidak menimbulkan masalah sosial, namun ada juga masyarakat yang menolak karena beranggapan bahwa perubahan tersebut tidak sesuai dengan norma dan nilai yang berlaku di daerahnya. Pada tahun 2009 terjadi konflik antara nelayan lokal dan nelayan andon yang membawa teknologi modern ke perairan Kedungrejo. Nelayan lokal yang masih menggunakan alat dan sarana tradisional menolak penggunaan mesin tempel pada perahu tangkap nelayan, masyarakat nelayan tersebut menganggap bahwa penggunaan mesin tempel membuat ikan takut dan kabur menjauh. Faktanya nelayan andon yang menggunakan mesin tempel pada perahunya mempermudah proses penangkapan karena bisa memecah besarnya ombak dan dapat menjangkau perairan yang lebih luas, hal tersebut menjadi pemicu konflik antar keduanya.

Perubahan masyarakat selalu diikuti oleh pengaruh dari faktor eksternal dan internal dalam masyarakat. Kedua faktor ini sangat mempengaruhi kondisi yang ada dalam masyarakat nelayan di Desa Kedungrejo Kecamatan Muncar Banyuwangi, faktor tersebut berpengaruh dalam segi :

\section{a. Nilai sosial}

Manusia merupakan makhluk sosial, yang artinya tidak dapat hidup tanpa bantuan manusia lain. Hubungan yang erat antar nelayan karena persamaan profesi membuat masyarakat nelayan memiliki rasa tenggang rasa yang tinggi, seperti gotong-royong saling membantu dan toleransi antar tetangga yang tinggi dalam masyarakat. Kegiatan gotongroyong serta saling membantu kepada sesama manusia tanpa mengharapkan pamrih merupakan salah satu nilai yang terdapat dalam rasa persatuan yang tinggi karena persamaan keadaan. Masyarakat nelayan Desa Kedungrejo menjunjung erat budaya gotong-royong, adanya perubahan sosial budaya yang merubah teknologi tradisional menjadi modern pada teknologi alat tangkap nelayan Kedungrejo ini meningkatkan 
budaya gotong-royong. Hal tersebut terlihat pada saat bulan purnama, masyarakat nelayan tidak melaut dan berkumpul di dermaga pelabuhaan untuk bersama-sama membenahi jaring yang rusak. Teknologi modern merubah alat tangkap jaring kecil menjadi alat tangkap gill net yang lebih besar sehingga memerlukan banyak nelayan yang membenahi bersama-sama sehingga meningkatkan rasa gotong-royong lebih besar.

\section{b. Nilai Kebudayaan}

Nilai kebudayaan dapat diartika sebagai suatu nilai yang disepakati dan menjadi landasan dalam suatu masyarakat, sebuah organisasi yang berupa simbol-simbol, kebiasaan, serta kepercayaan yang dianut masyarakat tersebut yang memiliki cirikhas dalam masing-masing daerah. Terdapat tiga bentuk dalam kebudayaan yaitu artefak atau benda-benda hasil budaya, gagasan, serta kebiasaan (Koentjaraningrat, 2005). Hal tersebut seperti adanya perubahan pada kebudayaan ritual petik laut yang semakin modern.

Masyarakat nelayan Kedungrejo memiliki kepercayaan bahwa setiap bulan muharram atau suro harus mengadakan ritual wajib petik laut. Namun terdapat perubahan dari jalannya ritual petik laut tersebut karena pengaruh modernisasi. Awalnya pemimpin acara tersebut merupakan seorang tetua adat, kini terdapat unsur islam yang menambahkan acara-acara agama seperti pengajian yang dipimpin oleh seorang kyai dalam ritual petik laut.

\section{SIMPULAN}

Terdapat Perubahan Kehidupan masyarakat nelayan Kedungrejo dari sebelum masuknya era modernisasi dan setelah masuknya era modernisasi. Awalnya teknologi dan sarana tangkap masyarakat nelayan Kedungrejo masih tradisional sehingga kurang untuk memenuhi kebutuhan sehari-hari. Namun kini setelah masuknya era modernisasi, kehidupan masyarakat nelayan Kedungrejo semakin sejahtera karena pendapatannya semakin meningkat. Hal itu disebabkan oleh kemajuan teknologi alat tangkap yang semakin modern dan mesin pada perahu yang mempermudah nelayan dalam mencari ikan.

Terdapat akulturasi dalam tradisi petik laut, yaitu antara nilai budaya lokal dan unsur agama islam. Dalam Ritual petik laut kini mengalami transformasi, awalnya berdasar pada unsur animisme dan dinamisme, seiring waktu berkembang ke dalam wujud yang berlandaskan pada keyakinan agama islam. Transformasi tersebut berupa, dulu tradisi petik laut hanya acara selametan biasa, namun seiring waktu terdapat perkembangan, yaitu kini Tradisi petik laut diselenggarakan secara kolosal, terdapat panitia formal yang mengatur suksesnya acara.

Musim paceklik merupakan musim dimana nelayan tidak melaut karena cuaca buruk sehingga tidak mendapatkan penghasilan dalam beberapa bulan. Masyarakat nelayan Kedungrejo memiliki budaya konsumtif yang tinggi, sebelum tahun 2017 yang lalu, masyarakat nelayan Kedungrejo sering mengalami musim paceklik namun hanya memiliki tabungan yang sedikit sehingga untuk biaya hidup sehari-hari mereka kesulitan sampai pada akhirnya menggelar fenomena piring terbang (menjual barang-barang). Namun setelah tahun 2017, masyarakat mendapat kebijakan dari pemerintah yaitu strategi menghadapi musim paceklik, sehingga kini fenomena piring terbang sudah tidak pernah digelar lagi.

Peniliti lanjutan yang ingin melakukan penelitian berkaitan dengan perubahan sosial budaya nelayan di pesisir Kedungrejo, Kecamatan Muncar Kabupaten Banyuwangi diharapkan agar kajian yang dilakukan perlu ditingkatkan 
lagi untuk menyempurnakan hasil penelitian terkait proses dan mekanisme perkembangan teknologi dan potensi budaya serta solusi untuk mengatasi kendala dalam rangka perubahan teknologi dan budaya di desa Kedungrejo.

\section{DAFTAR PUSTAKA}

Husen, S.I. (2015). Dinamika Perubahan Sosial Masyarakat Nelayan Dalam Meningkatkan Taraf Hidup di Kelurahan Mafututu Kota Tidore Kepulauan. Antropologi Indonesia. Vol. 33(2)

Imaniar, D. (2017) Pemberdayaan Masyarakat Pesisir (Perempuan Nelayan) Melalui Pemanfaatan Pengolahan Limbah Laut Dan Cangkang Kerang. Program Studi Ilmu Administrasi Publik, Universitas 17 Agustus 1945 Banyuwangi Humaniora, Vol. 14(2)

Juliantono, F.J. (2016) Fenomena Kemiskinan Nelayan: Perspektif Teori Strukturasi. Jurnal Politik Vol. 12(02).

Koentjaraningrat. (2005). Pengantar Antropologi Jilid 2. Jakarta: PT. Rineka Cipta.

Kurniadi, H. (2017) Pegembangan Peran Perempuan Pesisir Di Muncar: Analisis Dan Pemetaan Kualitas Sumber Daya Pada Perempuan Muda.

Marnelly, T. R. (2011) Dinamika Sosial Budaya Masyarakat Melayu Pesisir (Studi Pengelolaan Madu Sialang Di Desa Rawa Mekar Jaya). Jurnal Antropologi. Vol. 15(1)
Marzali, A. (2006). StrukturalFungsionalisme. Antropologi Indonesia. Vol. 30(2)

Mulyadi, M. (2011). Penelitian Kuantitatif dan Kualitatif serta Pemikiran Dasar Menggabungkannya. Jurnal Studi Komunikasi dan Media. Vol. 15(1).

Nugraheni S, W et al. (2012). Peran Dan Potensi Wanita Dalam Pemenuhan Kebutuhan Ekonomi Keluarga Nelayan. Jurnal Studi Pendidikan Sosial. Vol 1 (2)

Sajogyo dan Pudjiwati, (1996). Sosiologi Pedesaan. Gajah Mada University Press: Bogor.

Setiawan, E. (2016) Eksistensi Budaya Bahari Tradisi Petik Laut di Muncar Banyuwangi. Peneliti Masalah sosial, Alumnus Program Pascasarjana Sosiologi Universitas Brawijaya Malang. Vol. 10 (2)

Simanjuntak, Bungaran Antonius. (2016). Tradisi, Agama, dan Akseptasi Modernisasi pada Masyarakat Pedesaan Jawa. Jakarta: Yayasan Pustaka Obor Indonesia.

Wahyuningsih, (2015). Kondisi Sosial Ekonomi Masyarakat Nelayan (Studi Kasus terhadap Komunitas Nelayan Desa Landangan, Kapongan, Situbondo).

Wahyu, R. (2016). "Makna Simbolik Tradisi Sedekah Bumi Legenanan Pada Masyarakat Desa Kalirejo Kecamatan Talun Kabupaten Pekalongan". Skripsi Sosiologi dan Antropologi Universitas Negeri Semarang. 
Wardiat, D. (2017). Dinamika Nilai Gotong Royong Dalam Pranata Sosial Masyarakat Nelayan: Studi Kasus Masyarakat Bulutui Dan Pulau Nain, Sulawesi .Utara. Jurnal Kebudayaan sosial. Vol. 13(2)

Yusuf, A.M. (2017). Metode Penelitian: Kuantitatif, Kualitatif, dan Penelitian Gabungan. Jakarta: PT. Fajar Interpratama Mandiri.

Zamzami, L. (2009). Sistem Pengetahuan Lokal Nelayan Terhadap Teknologi Penangkapan Ikan pada Masyarakat Pasar Laban, Kecamatan Buangus Teluk Kabung, Kota Padang. Dalam Jurnal Fenomena Vol.7(2)

Zamzami, L. (2010). Pemberdayaan Ekonomi Masyarakat Pesisir di Nagari Ampiang Perak, Sumatera Barat. Vol. 19 (2)

Zamzami, L. (2016). Dinamika Pranata Sosial Terhadap Kearifan Lokal Masyarakat Nelayan Dalam Melestarikan Wisata Bahari. Jurnal Antropologi: Isu-Isu Sosial Budaya.Vol.18 (1). 